\title{
A Study of the Cost and Returns of Milk Production of Cow and Buffalo and to Find Out the Break-Even Point of Dairy Enterprise; in Faizabad District of Eastern Uttar Pradesh, India
}

\author{
Jitendra Kumar Singh, Rajeev Singh ${ }^{*}$, J.P. Singh, Santosh Kumar Mishra, \\ Rajeev Kumar and Tushar Raghuvanshi
}

\author{
Department of Agricultural Economics Narendra Deva University of Agriculture and \\ Technology Kumarganj, Faizabad (U.P.) 224229, India \\ *Corresponding author
}

\begin{tabular}{|c|c|}
\hline & A B S T R A C T \\
\hline & $\begin{array}{l}\text { Animal husbandry \& dairy play an important role in national economy and in socio- } \\
\text { economic development of the country. Animal husbandry output constitutes about } 30 \text { per } \\
\text { cent of the country's agricultural output. The programme has completed its III phase in } \\
\text { April 1996.The Operation Flood Programme, which is the world's largest integrated dairy } \\
\text { development programme has made considerable progress in achieving its outlined } \\
\text { objectives. During 2014-15, } 132.43 \text { million tones of milk were produced and per capita }\end{array}$ \\
\hline Keywords & $\begin{array}{l}\text { availability was } 296 \text { gram/day in the country. A list of livestock owners was prepared in } \\
\text { ascending order on the basis of livestock. The livestock owner having } 1,2-3 \& 4 \text { and }\end{array}$ \\
\hline $\begin{array}{l}\text { Weighted Mean, } \\
\text { Tabular analysis. }\end{array}$ & $\begin{array}{l}\text { above number of cows and buffaloes were classified as small, medium and large livestock } \\
\text { owners, respectively. The primary data was collected by survey technique with the help of }\end{array}$ \\
\hline Article Info & $\begin{array}{l}\text { pretested schedule while relevant secondary data was collected from various Government } \\
\text { offices and published records were viewed and recorded. Tabular and functional analysis }\end{array}$ \\
\hline $\begin{array}{l}\text { Accepted: } \\
\text { 28 September } 2017 \\
\text { Available Online: } \\
10 \text { November } 2017\end{array}$ & $\begin{array}{l}\text { of collected data was carried out. The structure of sample farms highlights overall } \\
\text { conditions within and around the farms such as size of holding, family size, age, and } \\
\text { literacy percentage etc. The results revealed overall average cost was Rs. } 17685.29 \text { and } \\
21739.73 \text { cows and buffaloes respectively. The cost of production of milk per liter in the }\end{array}$ \\
\hline & $\begin{array}{l}\text { cow and buffalo were recorded as Rs. } 12.77 \text { and Rs. } 14.70 \text { respectively. On an average the } \\
\text { gross returns from large household of cow was highest Rs.177.94. and buffalo was } \\
\text { Rs. } 243.29 \text {. Input-output ratio in milch animal (cow and buffalo) } 1: 2.50 \text { and } 1: 3.26 \text {. On an } \\
\text { overall average, the total milk production per milch animal per lactation was } 1560.64 \text { litres } \\
\text { for cow and } 1683.96 \text { litres for buffalo. On an overall average, the break-even point was } \\
\text { found to be } 3.75 \text { per cent of cow and } 2.30 \text { per cent of buffalo to total milk yield. }\end{array}$ \\
\hline
\end{tabular}

\section{Introduction}

India stands first, whereas USA stands second in the world in milk production. India constitutes in milk production, accounting for 17 per cent of world production. During 2015-16, milk production peaked at 137.97 million tones. Thus becoming an important secondary source of income for 70 million rural households engaged in dairying and for 70 per cent of the workforce that comprised women. The average year-on-year growth rate of milk at 4.04 per cent vis-a-vis the world aver-age of 2.2 per cent shows sustained 
growth in availability of milk and milk products for the growing population. About 80 per cent of milk produced in the country is in the organized sector and the remaining 20 per cent is shared equally by cooperatives and private dairies. Over 1.33 lakh village level dairy cooperative societies, spread over 265 districts in the country, collect about 25.1 million litres of milk per day, and market about 20 million litres.

Animal husbandry \& dairy play an important role in national economy and in socioeconomic development of the country. Animal husbandry output constitutes about 30 per cent of the country's agricultural output. The fisheries sector contributed 0.7 per cent of the total GDP at factor cost and 4.6 per cent of GDP at factor cost from agriculture, forestry, and fishing in the year 2015-16.

The value of output from livestock sector at current prices was about Rs. 537535 crore during 2014-15 which is about 25.63 per cent of the value of output from agricultural, fishing and forestry sector, at current price and 26.02 per cent at constant prices (200405). Livestock sector provides regular employment to 11 million in principal status and 9 million in subsidiary status. Women constitute 70 per cent of the labour force in livestock sector as against 35 per cent in crop farming.

The $18^{\text {th }}$ livestock census has been conducted throughout the country with reference date of October 15, 2007. This census places the total livestock population at 529.7 million and poultry birds at 648.8 million. India ranks first in respect of buffalo, $2^{\text {nd }}$ in cattle and goats, $3^{\text {rd }}$ in sheep, $4^{\text {th }}$ in ducks, $5^{\text {th }}$ in chickens and $6^{\text {th }}$ in camel population in the world. Livestock contributed 137.97 million tones of milk, 69.73 billion eggs, and 44.73 million $\mathrm{kg}$ of wool, 2.68 million tones of meat, and 9.45 million tones of fish during 2015-16.
White revolution is associated with a sharp increase in milk production. During 1964-65, Intensive Cattle Development Programme (ICDP) was introduced in the country in which a package of improved animal husbandry was given to cattle owners for promoting white revolution in the country. Later on, to accelerate the pace of white revolution, a new programme named 'Operation Flood' was started in 1970 by National Dairy Development Board (NDDB). The programme has completed its III phase in April 1996.The Operation Flood Programme, which is the world's largest integrated dairy development programme has made considerable progress in achieving its outlined objectives. During 2014-15, 132.43 million tones of milk were produced and per capita availability was 296 gram/day in the country (Department of Animal Husbandry, Dairying \& Fisheries Ministry of Agriculture, Government of India, New Delhi).

The great story of India's "White Revolution" in livestock sector has several facts each presenting a success story which is unmatched in terms of its impact on rural economy. Nutritional benefits and social upliftment are the determinant of our agriculture growth. This success story of milk could have much larger dimensions with the higher population of indigenous cattle come under the umbrella of genetic improvement. Even when the growth in the sector in recent years has partially slowed down than what was seen during the previous two decades yet a growth rate of around four per cent in this sector provides ample testimony to capacity building and contribution of this commodity to the annual national growth.

Marketing of liquid milk occupies and important place in the dairy industry. A major portion of the liquid milk is marketed by the private or venders more commonly known as "dudhias". They are very popular in cities, but 
the urban consumers are not fully aware of the extent and nature of dilution practices adopted by majority of the milk vendors. Whereas other problems like loan for purchasing of milch animals, long marketing channels, higher middle men margin, lack of transport and chilling centers were generally faced by the farmers belonging to the villages.

The most significant contribution of the cooperative dairying is to bridge gap between the rural producers with the urban consumers, through the national milk grid. It has been able to bring the lucrative urban market to the door step of the dairy farmers, which is otherwise inaccessible to him. Although rapid increase in milk output is now underway in the country as a result of widespread use of co-operative system of dairy development.

Recently increase in demand of milk has not been matched by increase in supply. To meet that challenge ahead, greater emphasis needs to be placed on facilities in the area of milk production, processing, marketing, and research. It is therefore, imperative to identify all relevant factors associated with milk production in the country. The important factors affecting milk output are noted as (1) Quality and number of milch animals, (2) Investment in the dairying and (3) Marketing network. All of them are closely related with returns which are determined by cost of milk production, price spread, and marketable surplus. Hence, there is large scope to increase milk production of milch animals because they are poorly maintained on small farms. Adequate management, feedings, health care practices, and improved breeds are not available to marginal and small farmers.

\section{Materials and Methods}

This study involves a comprehensive data base of which most are primary in respect to their origin. Keeping in view the limitation of material resources and time factor, the study was conducted using sample survey method for collection of relevant information. Sampling design, method of data collection and specification of analytical tools, all these together, constitute the methodological part of present study. The chapter is solely devoted for a detailed discussion on these aspects.

\section{Sampling design}

Purposive cum random sampling technique was used for the selection of district, block, villages, and sample of livestock owners in the ultimate stage of study.

\section{Selection of district}

Faizabad district of Uttar Pradesh was selected purposively in order to avoid operational inconvenience.

\section{Selection of block}

Out of 11 blocks of Faizabad district, Amaniganj block having highest milk production was selected purposively.

\section{Selection of villages}

Thereafter, a list of all villages falling under the Amaniganj block were prepared from the records of block headquarter and five villages from the list were selected randomly.

\section{Selection of livestock owners}

A list of livestock owners was prepared in ascending order on the basis of number of livestock and divided into three group's viz., small, medium and large on the basis of number of livestock. The livestock owner having 1, 2-3 \& 4 and above number of cows and buffaloes were classified as small, medium and large livestock owners, respectively. 
From this list, a sample of 100 respondents was selected following the proportionate random sampling technique.

\section{Method and techniques}

\section{Collection of data}

The study consisted both primary and secondary data. For the collection of secondary information, various Government offices and published records were viewed and recorded. However, for the collection of primary field data the survey method was used.

The primary data from 100 sample livestock owners (60 small, 26 medium, and 14 large size groups) were collected through a well prepared and pretested schedule of enquiry by personal interview technique to pertain various objective of the study from the sample livestock owners.

The data were recorded for the complete lactation period for each milch animal.

\section{Period of enquiry}

The data pertained for the agricultural reference year 2015-16.

\section{Analytical tools}

Analytical tools used for the analysis and interpretations of the data have been presented as below.

\section{Tabular analysis}

Tabular analysis was used to compare the different parameters among marginal, small, medium and large size group of the farmer.

Family composition, investment pattern; cropwise costs and returns etc. computed and presented in tabular forms. In this computation weighted average is used.

\section{Weighted average}

The weighted average of the variable $\mathrm{X}$ was calculated by using following formula.

$\mathrm{W} . \mathrm{A} .=\frac{\sum \mathrm{W}_{\mathrm{i}} \mathrm{X}_{\mathrm{i}}}{\sum \mathrm{W}_{\mathrm{i}}}$

Where,

$\mathrm{X}_{\mathrm{i}}=$ Weighted value of an item

$\mathrm{W}_{\mathrm{i}}=$ Weight of $\mathrm{X}_{\mathrm{i}}$

\section{Break-even point}

Break-even point analysis was employed to workout breakeven output for milch animals (cow and buffalo) on different categories of livestock owners.

\section{TFC \\ BEP = -------------}

Where,

$\mathrm{BEP}=$ Break-even point in litres of milk.

TFC $=$ Total fixed cost per milch animal in rupees.

ASP $=$ Average selling price per litre of milk (Rs.).

AVC $=$ Average variable cost per litre of milk (Rs.).

\section{Results and Discussion}

Production and maintenance cost of per milch animal (cows and buffaloes) per day

The various cost components including in rearing of a milch cow per day for different categories of household have been given in Table 2. 
The total cost of milk production per milch animal (cows and buffaloes) per day on small, medium, and large households; category was estimated having Rs. 49.09 and Rs.60.00, Rs. 58.90 and Rs.71.99, and Rs. 36.51 and Rs.44.52, respectively with an overall average was Rs. 48.45 and Rs.59.56. The fodder cost was the most important item of total maintenance cost accounting for maximum on medium Rs.36.86 and Rs.45.06, small Rs.29.70 and Rs.36.31 and large Rs. 19.53 and Rs.23.87, respectively whereas maximum is concentrate estimated in medium Rs. 17.60 and Rs. 21.51 followed by small Rs. 12.81 and 15.66, large Rs. 4.62 and 5.65 with an overall average having Rs. 11.87 and 14.63 in both cows and buffaloes, respectively.

The labour cost was recorded maximum in case of large households followed by medium, and small, category of households. The Veterinary charges were found highest Rs. 0.83 and 1.02, and Rs. 0.64 and Rs. 0.78 for small and medium households, respectively and lowest Rs. 0.48 and Rs. 0.48 for large households.

The fixed cost was decreasing at increasing trend with the small, medium, and large category of households, whereas an overall average was found Rs. 1.99, and Rs. 2.40. The overall variable cost was recorded Rs. 46.46 and 57.16 along with overall costs was found Rs. 48.45 and Rs.59.56 in case of cow and buffalo, respectively.

The total cost of milk production per milch animal (cows and buffaloes) per day on small, medium, and large households; category was estimated having Rs. 49.09 and Rs.60.00, Rs. 58.90 and Rs.71.99, and Rs. 36.51 and Rs.44.52, respectively with an overall average was Rs. 48.45 and Rs.59.56. The fodder cost was the most important item of total maintenance cost accounting for maximum on medium Rs.36.86 and Rs.45.06, small
Rs.29.70 and Rs.36.31and large Rs. 19.53 and Rs.23.87, respectively whereas maximum is concentrate estimated in medium Rs. 17.60 and Rs. 21.51 followed by small Rs. 12.81 and 15.66, large Rs. 4.62 and 5.65 with an overall average having Rs. 11.87 and 14.63 in both cows and buffaloes, respectively.

Production and maintenance cost of per milch animal (cows and buffaloes) per annum (in Rs.)

The different items considered in the production and maintenance costs are given in Table 3. It was observed that total production and maintenance cost in cow per annum was highest in Rs. 21497.71 and lowest Rs. 13326.24 in case of medium households and large households respectively. It was further observed that the total production and maintenance costs were also found highest Rs. 26274.98 for medium household and lowest Rs. 16248.91 for large in the case of buffalo. Total cost was observed in the cow Rs. 13326.24, 21497.71, and 17918.03 whereas in case buffalo was Rs. 16248.91, Rs. 26274.98, and Rs. 21899.81 for large, medium, and small, households, respectively.

Among various categories of milch animal the fodder cost was highest for medium household Rs. 13456.47 and Rs.16446.79 and lowest for marginal Rs.7128.24 and Rs.8712.30. The concentrates cost was found highest for medium household Rs. 6423.63 and Rs.7851.10 lowest for large Rs.1686.44 and Rs.2061.20 in the case of cow and buffalo whereas, the labour charges was highest for large and small households Rs. 3762.29 and Rs. 4598.36, and 1172.25 and 1432.75 respectively except to medium Rs. 496.30 and Rs. 606.59 and Veterinary charges was found highest Rs. 304.27 and 371.89, and Rs. 233.05 and Rs. 284.84 for small and medium households, respectively and lowest Rs. 174.22 and Rs.174.22 for large households. 
The results revealed overall average cost was Rs. 17685.29 for cows and Rs. 21739.73 for buffaloes.

The cost of fodder, concentrates, mineral material, labour charges, Veterinary charges, and fixed cost on overall basis were 59.72, $24.50,0.44,9.87,1.36$, and 4.10 percent, respectively in case of cows and in the case of buffaloes it was is 59.78, 24.56, 0.43, 9.95, 1.25 , and 4.02 per cent, respectively.

\section{Per litre costs of milk production}

The cost of production of milk is directly related to the net return of the product. An analysis of the costs of milk production is an indicator of profitability of the enterprise.

The per liter costs of milk production per lactation is presented in Table 4.

The results reflects that the total cost and milk production per animal per lactation for various size groups of milch cow were Rs. 17918.03 and 1361.36 liter, Rs. 21497.71 and 1545.53 liter, and Rs. 13326.24 and 1811.68 liter for small, medium and large households, respectively with an overall was Rs. 17685.29 and 1560.64 liter. The per liter cost of milk production on small, medium and large size groups were estimated to be Rs. 13.16, 13.91, and 11.09 , respectively. In the case of milch buffalo were Rs. 21899.81 and 1479.37 litres,
Rs. 26274.98 and 1677.15 litres and Rs. 16248.91 and 1860.82 litres for small, medium, and large households, respectively with an overall average was Rs. 21739.73 and 1684.43 litres. The per litre cost of milk production on small, medium and large size groups were estimated 14.80, 15.67, and 13.48 , respectively. The overall average cost of production of milk per liter in the milch cow was Rs. 12.77 and Rs. 14.70 in milch buffalo.

\section{Costs and returns of milk production of per milch animal per day}

Per day returns from milk production on all the categories of cow and buffalo are given in Table 5. On an average the gross returns from large household of cow was highest Rs.177.94 and it decreased from medium to small households. However, in the case of buffalo, the gross return from large household was also highest Rs.243.29 followed by medium and small size of households respectively. Overall, the gross return in case of cow was Rs. 153.66 and buffalo was Rs. 220.57 .

The input-output ratio in milch cow was highest on large 1:3.22 size group followed by medium and small while in case of buffalo input-output ratio was also highest on large 1:3.5 size groups followed by medium and small households, respectively.

Table.1 Village - wise selected farmers under different size groups

\begin{tabular}{|l|c|c|c|c|c|c|c|c|}
\hline \multirow{2}{*}{ Name of village } & \multicolumn{9}{|c|}{ Size groups(ha) } \\
\cline { 2 - 9 } & \multicolumn{2}{|c|}{ Small } & \multicolumn{2}{c|}{ Medium } & \multicolumn{2}{c|}{ Large } & \multicolumn{2}{c|}{ Total } \\
\cline { 2 - 9 } & P & S & P & S & P & S & P & S \\
\hline Devgaon & 120 & 15 & 66 & 6 & 40 & 3 & 226 & 24 \\
\hline Dhamthua & 95 & 12 & 50 & 4 & 25 & 2 & 170 & 18 \\
\hline Amavasufi & 90 & 10 & 45 & 4 & 30 & 3 & 165 & 17 \\
\hline Biraulijhan & 115 & 12 & 78 & 7 & 42 & 4 & 235 & 23 \\
\hline Amarganj & 107 & 11 & 73 & 5 & 24 & 2 & 204 & 18 \\
\hline Total & 527 & 60 & 312 & 26 & 161 & 14 & 1000 & 100 \\
\hline
\end{tabular}

Where, $\mathrm{P}=$ Population, $\mathrm{S}=$ Sample 
Table.2 Production and maintenance cost of per milch animal (cows and buffaloes) per day. (in Rs.)

\begin{tabular}{|c|c|c|c|c|c|c|c|c|c|c|c|c|c|c|c|c|c|}
\hline \multirow{3}{*}{ S. No. } & \multirow{3}{*}{ Particulars } & \multicolumn{16}{|c|}{ Categories of households } \\
\hline & & \multicolumn{4}{|c|}{ Small } & \multicolumn{4}{|c|}{ Medium } & \multicolumn{4}{|c|}{ Large } & \multicolumn{4}{|c|}{ Overall } \\
\hline & & Cow & $\%$ & Buffalo & $\%$ & Cow & $\%$ & Buffalo & $\%$ & Cow & $\%$ & Buffalo & $\%$ & Cow & $\%$ & Buffalo & $\%$ \\
\hline 1. & Dry fodder & 19.40 & 39.53 & 23.72 & 39.53 & 24.32 & 41.29 & 29.73 & 41.29 & 13.51 & 37.00 & 16.51 & 37.09 & 19.21 & 39.65 & 23.68 & 39.76 \\
\hline 2. & Green fodder & 10.30 & 20.99 & 12.59 & 20.99 & 12.54 & 21.30 & 15.33 & 21.30 & 6.02 & 16.49 & 7.36 & 16.53 & 9.72 & 20.07 & 11.93 & 20.03 \\
\hline 3. & Conce-ntrate & 12.81 & 26.10 & 15.66 & 26.10 & 17.60 & 29.88 & 21.51 & 29.88 & 4.62 & 12.66 & 5.65 & 12.68 & 11.87 & 24.50 & 14.63 & 24.56 \\
\hline a. & Grain & 5.12 & 10.44 & 6.26 & 10.44 & 7.04 & 11.95 & 8.60 & 11.95 & 1.85 & 5.06 & 2.26 & 5.07 & 4.75 & 9.80 & 5.85 & 9.82 \\
\hline b. & Khali & 3.20 & 6.52 & 3.91 & 6.52 & 4.40 & 7.47 & 5.38 & 7.47 & 1.16 & 3.16 & 1.41 & 3.17 & 2.97 & 6.12 & 3.66 & 6.14 \\
\hline c.. & $\begin{array}{l}\text { Chunni/ } \\
\text { Choker }\end{array}$ & 4.48 & 9.13 & 5.48 & 9.13 & 6.16 & 10.46 & 7.53 & 10.46 & 1.62 & 4.43 & 1.98 & 4.44 & 4.15 & 8.57 & 5.12 & 8.60 \\
\hline 4. & $\begin{array}{l}\text { Mineral } \\
\text { material }\end{array}$ & 0.26 & 0.54 & 0.32 & 0.54 & 0.30 & 0.51 & 0.37 & 0.51 & 0.06 & 0.17 & 0.08 & 0.17 & 0.21 & 0.44 & 0.26 & 0.43 \\
\hline 5. & Labor charge & 3.21 & 6.54 & 3.93 & 6.54 & 1.36 & 2.31 & 1.66 & 2.31 & 10.31 & 28.23 & 12.60 & 28.30 & 4.78 & 9.88 & 5.92 & 9.95 \\
\hline 6. & $\begin{array}{l}\text { Veterinary } \\
\text { charges }\end{array}$ & 0.83 & 1.70 & 1.02 & 1.70 & 0.64 & 1.08 & 0.78 & 1.08 & 0.48 & 1.31 & 0.48 & 1.07 & 0.66 & 1.36 & 0.74 & 1.25 \\
\hline 7. & $\begin{array}{l}\text { Variable cost (S. } \\
\text { No. 1-6) }\end{array}$ & 46.83 & 95.39 & 57.24 & 95.39 & 56.77 & 96.38 & 69.38 & 96.38 & 35.00 & 95.85 & 42.67 & 95.84 & 46.46 & 95.90 & 57.16 & 95.98 \\
\hline 8. & Fixed cost & 2.26 & 4.61 & 2.76 & 4.61 & 2.13 & 3.62 & 2.61 & 3.62 & 1.51 & 4.15 & 1.85 & 4.16 & 1.99 & 4.10 & 2.40 & 4.02 \\
\hline \multicolumn{2}{|c|}{ Grand-total $(\mathrm{V}+\mathrm{F})$} & 49.09 & 100 & 60.00 & 100 & 58.90 & 100 & 71.99 & 100 & 36.51 & 100 & 44.52 & 100 & 48.45 & 100 & 59.56 & 100 \\
\hline
\end{tabular}

Table.3 Production and maintenance cost of per milch animal (cows and buffaloes) per annum (in Rs.)

\begin{tabular}{|c|c|c|c|c|c|c|c|c|c|c|c|c|c|c|c|c|c|}
\hline \multirow{3}{*}{ S. No. } & \multirow{3}{*}{ Particulars } & \multicolumn{16}{|c|}{ Categories of households } \\
\hline & & \multicolumn{4}{|c|}{ Small } & \multicolumn{4}{|c|}{ Medium } & \multicolumn{4}{|c|}{ Large } & \multicolumn{4}{|c|}{ Overall } \\
\hline & & Cow & $\%$ & Buffalo & $\%$ & Cow & $\%$ & Buffalo & $\%$ & Cow & $\%$ & Buffalo & $\%$ & Cow & $\%$ & Buffalo & $\%$ \\
\hline 1. & Dry fodder & 7082.64 & 39.53 & 8656.56 & 39.53 & 8877.76 & 41.30 & 10850.59 & 41.30 & 4931.04 & 37.00 & 6026.83 & 37.09 & 7012.40 & 39.65 & 8644.30 & $\begin{array}{r}39.7 \\
6 \\
\end{array}$ \\
\hline 2. & Green fodder & 3760.78 & 20.99 & 4596.51 & 20.99 & 4578.71 & 21.30 & 5596.20 & 21.30 & 2197.20 & 16.49 & 2685.47 & 16.53 & 3549.33 & 20.07 & 4353.32 & $\begin{array}{r}20.0 \\
2 \\
\end{array}$ \\
\hline 3. & Concentrate & 4676.17 & 26.10 & 5715.32 & 26.10 & 6423.63 & 29.88 & 7851.10 & 29.88 & 1686.44 & 12.66 & 2061.20 & 12.69 & 4332.34 & 24.50 & 5338.65 & $\begin{array}{r}24.5 \\
6 \\
\end{array}$ \\
\hline a. & Grain & 1870.47 & 10.44 & 2286.13 & 10.44 & 2569.45 & 11.95 & 3140.44 & 11.95 & 674.57 & 5.06 & 824.48 & 5.07 & 1732.93 & 9.80 & 2135.46 & 9.82 \\
\hline b. & Khali & 1169.04 & 6.52 & 1428.83 & 6.52 & 1605.91 & 7.47 & 1962.77 & 7.47 & 421.61 & 3.16 & 515.30 & 3.17 & 1083.08 & 6.12 & 1334.66 & 6.14 \\
\hline c.. & $\begin{array}{l}\text { Chunni/ } \\
\text { Choker }\end{array}$ & 1636.66 & 9.13 & 2000.36 & 9.13 & 2248.27 & 10.46 & 2747.88 & 10.46 & 590.25 & 4.43 & 721.42 & 4.44 & 1516.32 & 8.57 & 1868.53 & 8.59 \\
\hline 4. & Mineral material & 96.52 & 0.54 & 117.97 & 0.54 & 110.22 & 0.51 & 134.710 & 0.51 & 22.50 & 0.17 & 27.5 & 0.17 & 78.26 & 0.44 & 94.41 & 0.43 \\
\hline 5. & Labor charge & 1172.25 & 6.54 & 1432.75 & 6.54 & 496.30 & 2.31 & 606.59 & 2.31 & 3762.29 & 28.23 & 4598.36 & 28.30 & 1746.35 & 9.87 & 2162.50 & 9.95 \\
\hline 6. & Veterinary_charges & 304.27 & 1.70 & 371.89 & 1.70 & 233.05 & 1.08 & 284.84 & 1.08 & 174.22 & 1.31 & 174.22 & 1.07 & 240.78 & 1.36 & 271.71 & 1.25 \\
\hline 7. & $\begin{array}{l}\text { Variable cost (S. No. } \\
\text { 1-6) }\end{array}$ & 17092.66 & 95.39 & 20891.02 & 95.39 & 20719.67 & 96.38 & 25324.04 & 96.38 & 12773.70 & 95.85 & 15573.58 & 95.84 & 16959.47 & 95.90 & 20864.88 & $\begin{array}{r}95.9 \\
8 \\
\end{array}$ \\
\hline 8. & Fixed cost & 825.37 & 4.61 & 1008.79 & 4.61 & 778.04 & 3.62 & 950.94 & 3.62 & 552.54 & 4.15 & 675.33 & 4.16 & 725.82 & 4.10 & 874.85 & 4.02 \\
\hline \multicolumn{2}{|c|}{ Grand-total $(\mathbf{V}+\mathbf{F})$} & 17918.03 & 100 & 21899.81 & 100 & 21497.71 & 100 & 26274.98 & 100 & 13326.24 & 100 & 16248.91 & 100 & 17685.29 & 100 & 21739.73 & 100 \\
\hline
\end{tabular}


Table.4 Cost of milk production of cow and buffalo in different categories of households (Rs/milch animal/lactation)

\begin{tabular}{|c|c|c|c|c|}
\hline \multirow{2}{*}{ Particular } & \multicolumn{3}{|c|}{ Categories of households (Cow) } & \multirow{2}{*}{ Overall } \\
\hline & Small & Medium & Large & \\
\hline \multicolumn{5}{|l|}{ Cow } \\
\hline Total cost (Rs.) & 17918.03 & 21497.71 & 13326.24 & 17685.29 \\
\hline Total milk production litre & 1361.36 & 1545.53 & 1811.68 & 1560.64 \\
\hline Cost of milk production/litres (Rs.) & 13.16 & 13.91 & 11.09 & 12.77 \\
\hline \multicolumn{5}{|l|}{ Buffalo } \\
\hline Total cost (Rs.) & 21899.81 & 26274.98 & 16248.91 & 21739.73 \\
\hline Total milk production litre & 1479.37 & 1677.15 & 1860.82 & 1684.43 \\
\hline Cost of milk production/litres (Rs.) & 14.80 & 15.67 & 13.48 & 14.70 \\
\hline
\end{tabular}

Table.5 Costs and returns of milk production of per milch animal per day

\begin{tabular}{|c|c|c|c|c|c|c|c|c|}
\hline \multirow{3}{*}{ Particulars } & \multicolumn{8}{|c|}{ Categories of milch animal } \\
\hline & \multicolumn{4}{|c|}{$\begin{array}{r}\text { Cow } \\
\end{array}$} & \multicolumn{4}{|c|}{ Buffalo } \\
\hline & Small & Medium & Large & Overall & Small & Medium & Large & Overall \\
\hline $\begin{array}{l}\text { Total cost of production } \\
\text { (Rs.) }\end{array}$ & 49.09 & 58.90 & 36.51 & 48.45 & 60.00 & 71.98 & 44.51 & 59.55 \\
\hline Milk yield (litre) & 4.39 & 4.98 & 5.84 & 5.03 & 4.77 & 5.41 & 6.00 & 5.43 \\
\hline Price of milk (Rs./litre) & 30.00 & 30.00 & 30.00 & 30.00 & 40.00 & 40.00 & 40.00 & 40.00 \\
\hline Value of dung (Rs./day) & 2.74 & 2.74 & 2.74 & 2.74 & 3.29 & 3.29 & 3.29 & 3.29 \\
\hline Gross return (Rs.) & 134.44 & 152.14 & 177.94 & 153.66 & 194.09 & 219.69 & 243.29 & 220.57 \\
\hline Net profit (Rs.) & 85.35 & 93.24 & 122.85 & 99.49 & 134.09 & 147.71 & 174.58 & 152.95 \\
\hline Cost benefit ratio & $1: 2.74$ & $1: 1.58$ & $1: 3.22$ & $1: 2.50$ & $1: 3.23$ & $1: 3.05$ & $1: 3.54$ & $1: 3.26$ \\
\hline
\end{tabular}

Table.6 Break-even point (BEP) for milch cow on different categories

\begin{tabular}{|l|c|c|c|c|}
\hline \multicolumn{1}{|c|}{ Particular of BEP } & \multicolumn{3}{c|}{ Categories of households } \\
\cline { 2 - 5 } & Small & Medium & Large & Overall \\
\hline Milk yield animal (litre) day/lactation/annum & 1361.36 & 1545.53 & 1811.68 & 1560.64 \\
\hline Fixed cost per animal (Rs.) & 825.37 & 778.04 & 552.541 & 725.82 \\
\hline Variable cost per animal (Rs.) & 17092.66 & 20719.67 & 16959.47 & 18247.40 \\
\hline Total cost per animal (Rs.) & 17918.03 & 21497.71 & 20109.13 & 19772.33 \\
\hline Variable cost per litre of milk (Rs.) & 12.55 & 13.40 & 9.36 & 11.85 \\
\hline Price per litre of milk (Rs.) & 30.00 & 30.00 & 30.00 & 30.00 \\
\hline Break-even point (litre) & 47.30 & 46.87 & 87.77 & 59.61 \\
\hline Percentage of BEP to total output (BEP*100/Milk yield/ lactation) & 3.47 & 3.03 & 4.84 & 3.75 \\
\hline
\end{tabular}

Table.7 Break-even point (BEP) for milch buffalo on different categories

\begin{tabular}{|l|l|l|l|r|}
\hline \multirow{2}{*}{ Particular of BEP } & \multicolumn{2}{c|}{ Categories of households } \\
\cline { 2 - 5 } & \multicolumn{1}{c|}{ Small } & \multicolumn{1}{c|}{ Large } & \multicolumn{1}{c|}{ Overall } \\
\hline Milk yield animal (litre) day/lactation/annum & 1478.70 & 1677.10 & 1860.00 & 1683.96 \\
\hline Fixed cost per animal (Rs.) & 1008.79 & 950.94 & 675.33 & 874.85 \\
\hline Variable cost per animal (Rs.) & 20891.02 & 25324.04 & 15573.58 & 20864.88 \\
\hline Total cost per animal (Rs.) & 21899.81 & 26274.98 & 16248.91 & 21739.73 \\
\hline Variable cost per litre of milk (Rs.) & 15.35 & 15.10 & 8.37 & 12.92 \\
\hline Price per litre of milk (Rs.) & 40 & 40 & 40 & 40.00 \\
\hline Break-even point (litre) & 55.21 & 38.19 & 21.35 & 37.22 \\
\hline $\begin{array}{l}\text { Percentage of BEP to total output (BEP*100/Milk } \\
\text { yield/ lactation) }\end{array}$ & 3.73 & 2.28 & 1.15 & 2.30 \\
\end{tabular}


On an average input-output ratio in milch cow was highest on large 1:3.22 followed by medium 1:1.58, and small 1: 2.74 household. In the case of buffalo input-output ratio was also highest on large 1:3.54 followed by small 1:3.23 and medium 1:3.05 size groups of households.

\section{Break-even point of milk production of milch animals}

The break-even point analysis was done to estimate the minimum quantity of milk to be produced to cover the total cost on all the size groups of household for both the cow and buffalo are given in Table 6 and 7 .

It is estimated that the total cost per milch cow per annum was Rs. 17918.03, Rs. 21497.71, and Rs.20109.13, on small, medium, and large group of milch animals, respectively with an overall average was Rs. 19772.33.

Total costs per milch buffalo were Rs.21899.81, Rs.26274.98, Rs.16248.91, on small, medium and large size groups, respectively with an overall average was Rs.21739.73.

Irrespective of the size groups, the overall average on fixed costs per milch animal per annum was found Rs. 725.82 and Rs. 874.85 for the milch cow and buffalo, respectively.

It is clear from the Table that total variable costs per milch cow per annum on small, medium, and large were Rs. 17092.66, Rs. 20719.67, and Rs. 16959.47, respectively. In case milch buffalo, it was worked out on small (Rs. 20891.02), medium (Rs. 25324.04) and large (Rs. 15573.58) size group of milch animals. On an overall average, the total variable cost per milch animal per annum was estimated at Rs. 18247.40 and Rs. 20864.88 for milch cow and buffalo, respectively.
Table 4 and 6 further show that the total milk produced per milch cow per lactation on small, medium, and large size groups of milch animals was $1361.36,1545.53$, and 1811.68 litres, and the break-even output came to be 47.30, 46.87, and 87.77 litres on small, medium, and large size groups. In the case of per milch buffalo per lactation was 1478.70 , 1677.10 , and 1860.00 litres and the breakeven output was 55.21, 38.19, and 21.35 litres on the small, medium and large size group of milch animals, respectively. On an overall average, the total milk production per milch animal per lactation was 1560.64 litres for cow and 1683.96 litres for buffalo. Thus it is clear the milk yield per milch animal (cow and buffalo) per lactation was higher than its break-even output to cover the total cost of the size group of milch animals.

The break-even output worked out was 3.47, 3.03 , and 4.84 , per cent of the total milk yield on small, medium, and large size group of cow, respectively. In the case of buffalo milk, the break-even point was 3.73, 2.28, and 1.15, per cent of the total milk yield on small, medium, and large groups respectively. On an overall average, the break-even point was found to be 3.75 per cent of cow and 2.30 per cent of buffaloes to total milk yield. Thus it can be concluded that the break-even output was found maximum in large size group in cow and the buffalo was small size group of milch animal.

Animal husbandry \& dairy play an important role in national economy and in socioeconomic development of the country. Animal husbandry output constitutes about 30 per cent of the country's agricultural output. Livestock sector provides regular employment to 11 million in principal status and 9 million in subsidiary status. Women constitute 70 per cent of the labour force in livestock sector as against 35 per cent in crop farming. 
The programme has completed its III phase in April 1996.The Operation Flood Programme, which is the world's largest integrated dairy development programme has made considerable progress in achieving its outlined objectives. During 2014-15, 132.43 million tones of milk were produced and per capita availability was 296 gram/day in the country.

Milk being the highly perishable commodity, needs quick, and an efficient marketing system.

Recently increase in demand of milk has not been matched by increase in supply. To meet that challenge ahead, greater emphasis needs to be placed on facilities in the area of milk production, processing, marketing, and research. It is therefore, imperative to identify all relevant factors associated with milk production in the country. The important factors affecting milk output are noted as (1) Quality and number of milch animals, (2) Investment in the dairying and (3) Marketing network. All of them are closely related with returns which are determined by cost of milk production, price spread, and marketable surplus. Adequate management, feedings, health care practices, and improved breeds are not available to marginal and small farmers. These farmers are so poor that they cannot fulfill their dairy needs and basic problems.

A list of livestock owners was prepared in ascending order on the basis of livestock. The livestock owner having 1, 2-3 and 4 and above number of cows and buffaloes were classified as small, medium and large livestock owners, respectively. The number of milk producer in each category of households was proportion to their population in each village. The data pertained for the agricultural reference year 2015-16 Milk yield was recorded for the whole lactation period for each animal separately. The primary data was collected by survey technique with the help of pretested schedule while relevant secondary data was collected from various Government offices and published records were viewed and recorded. Tabular and functional analysis of collected data was carried out. The main green fodder was barseem and green mustered in winter season, maize, suddan chari, bajara, jawar, and green grasses were main green fodder in summer and rainy seasons. The main dry fodder was bhusa which was supplied in all season; paddy straw was fed more in winter, less in summer season. The concentrates fed were wheat grain, choker, dalia, oil cakes, and chuni for all the season. The mineral materials feeds were salt etc. for all the season.

The structure of sample farms highlights overall conditions within and around the farms such as size of holding, family size, age, and literacy percentage etc. The size group of family inversely related with the livestock activities; above to 15 year female members also plays an important role in most of the farm and livestock activities in the study area.

The average of sample farm family by size group of farm an overall average size of family was 10.00 which varied from 8.78 to 11.50 (small to large farms). Total sample farms of 100 were constituted by 30.50 per cent children, 42.93 per cent adult, and 26.57 per cent old age. It was noticed that major composition of family member belongs to age group of $15-55$ yrs.

The total cost of milk production per milch animal (cows and buffaloes) per day on small, medium, and large households; category was estimated having Rs. 49.09 and Rs.60.00, Rs. 58.90 and Rs.71.99, and Rs. 36.51 and Rs.44.52, respectively. The fodder cost was the most important item of total maintenance cost accounting for maximum on medium Rs.36.86 and concentrates are also estimated 
in medium Rs. 17.60 with an overall average having Rs. 11.87 and 14.63 in both cows and buffaloes, respectively. The labour cost was recorded maximum in case of large households. Veterinary charges were found highest Rs. 0.83 and 1.02, and Rs. 0.64 and Rs. 0.78 for small and medium households, respectively and lowest Rs. 0.48 and Rs. 0.48 for large households. The fixed cost was decreasing at increasing trend whereas an overall average was found Rs. 1.99, and Rs. 2.40. The overall variable cost was recorded Rs. 46.46 and 57.16 along with overall costs was found Rs. 48.45 and Rs.59.56 in case of cow and buffalo, respectively.

It was observed that total production and maintenance cost in cow per annum Rs. $13326.24,21497.71$, and 17918.03 whereas in case buffalo was Rs. 16248.91, Rs. 26274.98, and Rs. 21899.81 for large, medium, and small, households, respectively. The results revealed overall average cost was Rs. 17685.29 for cows and Rs. 21739.73 for buffaloes.

The overall average cost of production of milk per liter in the milch animal cow and buffalo were recorded as Rs. 12.77 and Rs. 14.70 respectively. On an average the gross returns from large household of cow was highest Rs.177.94. However, in the case of buffalo, the gross return from large household was also highest Rs.243.29. Overall, the gross return in case of cow was Rs. 153.66, and buffalo was Rs. 220.57. On an average inputoutput ratio in milch cow was highest on large
1:3.22. In the case of buffalo input-output ratio was also highest on large.

On an overall average, the total milk production per milch animal per lactation was 1560.64 litres for cow and 1683.96 litres for buffalo. Thus it is clear the milk yield per milch animal (cow and buffalo) per lactation was higher than its break-even output to cover the total cost of the size group of milch animals. On an overall average, the breakeven point was found to be 3.75 per cent of cow and 2.30 per cent of buffaloes to total milk yield.

\section{References}

Afridi, G. S. Ishaq, M. and Sarfraz Ahmad (2009). Estimation of costs and returns and factor productivity in livestock enterprise in northern areas, Pakistan. Pakistan Journal of Life and Social Sciences, 7(1):43-51.

Balishter and Singh, N. P. (1995). A study of cost and returns from buffaloes. Livestock Adviser, 20(11):3-8.

Dillon, C. R. (1993). Advanced breakeven analysis of agricultural enterprise budgets. Agricultural Economics, 9(2):127-143.

Shiyani, R. L. Singh, R. V. and Pandya, H. R. (199U Dairy Science, 48(6):399-403.

Vasani, M.R. Kuchhadiya, D.B. and Shiyani, R.L. (1992). Cost and returns of buffalo milk production in Rajkot district of Saurashtra. Indian Dairyman, 44(6):270-273.

\section{How to cite this article:}

Jitendra Kumar Singh, Rajeev Singh, J.P. Singh, Santosh Kumar Mishra, Rajeev Kumar and Tushar Raghuvanshi. 2017. A Study of the Cost and Returns of Milk Production of Cow and Buffalo and to Find Out the Break-Even Point of Dairy Enterprise; in Faizabad District of Eastern Uttar Pradesh, India. Int.J.Curr.Microbiol.App.Sci. 6(11): 3928-3938. doi: https://doi.org/10.20546/ijcmas.2017.611.459 